Tips om medisinsk litteratur, andre bøker, filmer og elektroniske medier

som bør anmeldes, sendes tidsskriftet@legeforeningen.no

\section{Praktisk om livet med kronisk sykdom}

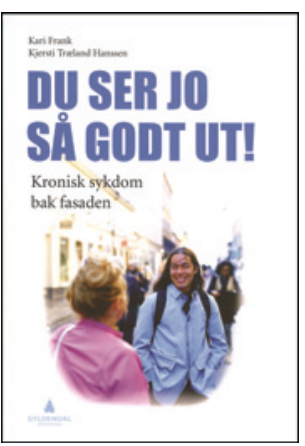

Kari Fran, Kjersti Træland Hanssen

\section{Du ser jo så godt ut!}

Kronisk sykdom bak fasaden. 241 s, ill.

Oslo: Gyldendal Akademisk, 2013

Pris NOK 375

ISBN 978-82-05-44533-8

Dette er en praktisk bok, en selvhjelpsbok, men også en bok for fagpersoner som er i posisjon til å yte «hjelp til selvhjelp». Intensjonen er å vise livet med kronisk sykdom bak fasaden. Boken er forankret i diagnosen multippel sklerose, men utfordringene som forfatterne beskriver, kan lett overføres til andre kroniske sykdommer.

Historiene understøttes av underkapitler med forklaringer, erfaringer og råd fra fagpersoner. Etter hvert tema gir forfatterne oss refleksjonsoppgaver, referanser og tips til videre lesning. Boken er ryddig og oversiktlig med en tiltalende layout. Forfatterne, som er spesialister i klinisk psykologi og klinisk nevropsykologi, henvender seg til alle som selv lever med kronisk sykdom, deres pårørende, venner og behandlere. Det er en bred målgruppe med både ulik kompetanse og bakgrunn.

Språket er dagligdags, men det bør ikke stoppe fagpersoner. Språk kan lett bli et hinder for god kommunikasjon om vanskelige temaer. Forfatterne gir et godt innblikk i et mangfold av behandlinger, egenhjelp og mulige løsninger. Nettopp det å finne løsninger til å leve med sykdommen hver eneste dag, står sentralt. De 17 kapitlene inneholder viktige temaer som å få en diagnose, søvn, fatigue, å være partner eller barn til kronisk syke, seksualitet, smerte og hverdagsplanlegging. Hvert kapittel har en god bredde i tilnærmingen til temaet. De kroppslige forandringene blir forklart sammen med emosjonelle og mer praktiske utfordringer.

Først syntes jeg historiene som innleder kapitlene, var litt lange. Etter hvert som jeg leste, så jeg likevel at det hadde sin verdi å følge historien helt ut. Jeg ble invitert inn i en annens hverdag med utfordringer i ulik valør.

Jeg har allerede anbefalt boken til kolleger som møter barn og voksne med kronisk sykdom.

\section{Birgitte L. Bjerkely}

Senter for sjeldne diagnoser

Oslo universitetssykehus, Rikshospitalet

\section{Fint om vaginisme}

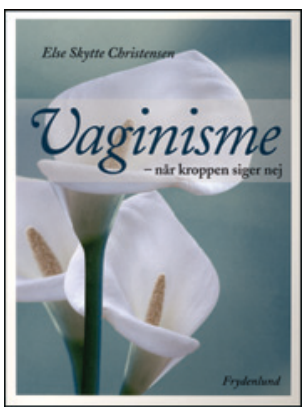

Else Skytte Christensen

Vaginisme

Når kroppen siger nej. 122 s, ill.

Frederiksberg: Frydenlund, 2013.

Pris DKK 199

ISBN 978-87-7118-129-6

Else Skytte Christensen er gynekolog og sexolog, og hun har arbeidet mange år både i sykehus og i egen praksis. Dette er først og fremst en selvhjelpsbok for kvinner med vaginisme, men den er også myntet på behandlere.

Det er to hoveddeler. I den første delen beskriver forfatteren vaginisme, i den andre er det behandlingsråd og øvelser. Teksten er supplert med en del kasuistikker. Det er noen få illustrasjoner i form av håndtegninger.

Språket er ledig og lettfattelig, og det burde ikke være noen hindring for nordmenn at den er skrevet på dansk.

Forfatteren går grundig gjennom hva vaginisme er, hva det skyldes, og hvilke psykologiske og fysiologiske mekanismer som spiller inn. Hun legger stor vekt på de reaksjonene og følelsene vaginisme kan utløse, og presiserer gjentatte ganger at man ikke bør skamme seg over å ha denne tilstanden. Hun går også inn på hvordan et parforhold kan påvirkes av at kvinnen har vaginisme, og problematikk med hensyn til barneønske.

Jeg synes hun forklarer og beskriver på en fin og empatisk måte, samtidig som det faglige innholdet er solid. Det kunne kanskje vært noen flere illustrasjoner, men det er ikke et viktig ankepunkt. Når det gjelder instruksjonene for egenøvelser, er jeg litt i tvil om leseren vil klare å gjennomføre dem uten støtte fra lege, men som supplement under et behandlingsforløp kan det fungere utmerket.

Alt i alt en fin liten selvhjelpsbok, som gjerne også kan leses av interesserte leger, studenter og annet helsepersonell. Vaginisme er en relativt sjelden tilstand, men svært problematisk for dem som lider av det, og det er viktig at de blir møtt på en god og kompetent måte.

\section{Pernille Nylehn}

Rehabilitering Vest

Haugesund 